\title{
Acute myocardial infarction and transient elevated anticardiolipin antibody in a young adult with possible familial hypercholesterolemia: a case report
}

\section{Anticardiolipin antibody and myocardial infarction}

Xin Su ${ }^{1,2}$, Aqian Wang ${ }^{1,2}$, Hai Zhu', Hongling Su', Yichao Duan ${ }^{1,3}$, Shanlian Wu², Min Zhang ${ }^{4}$, Yan Huang ${ }^{1}$, Xing Zhou ${ }^{5^{*}}$ and Yunshan $\mathrm{CaO}^{1 *}$ (i)

\begin{abstract}
Background: Familial hypercholesterolemia (FH) can lead to premature coronary heart disease. Anticardiolipin antibody may be a contributor for thrombosis. Here, we report an adult with possible FH suffered from premature myocardial infarction that may be triggered by transient increased anticardiolipin antibody.

Case presentation: A 29-year-old male had presented with a history of 2-h chest pain and numbness of left upper arm before 5 days. The electrocardiogram (ECG) had demonstrated inferior wall myocardial infarction (MI). Five days later he was admitted to our hospital and diagnosed as acute $\mathrm{Ml}$ and possible FH (premature coronary heart disease, low density lipoprotein cholesterol of $5.90 \mathrm{mmol} / \mathrm{L}$ ) with increased anticardiolipin antibody (up to $120 \mathrm{RU} / \mathrm{ml}$ ). Other auto-antibodies including $\beta 2$-glicoprotein antibodies IgM, IgA, IgG, lupus anticoagulant (LA), antinuclear antibodies, anti-myocardial antibody were normal. Coronary artery angiography (CAG) showed right coronary artery was total occlusion from the middle segment. Then he underwent percutaneous coronary intervention with a stent. Four days later, he was discharged with complete recovery. CAG showed intra-stent restenosis and anticardiolipin antibody level was normal and the patient had no any symptoms at 6-month follow-up.
\end{abstract}

Conclusions: Transient elevated anticardiolipin antibody may be a trigger or biomarker of cardiac thrombotic events in younger atherosclerotic patients.

Keywords: Familial hypercholesterolemia, Thrombosis, Myocardial infarction, Anticardiolipin antibody

\section{Background}

It is well known that the incidence of premature cardiovascular disease (CVD) is low. Previous studies have revealed that patients aged less than 40 years old only account for $1.2 \%$ of all patients with MI [1, 2]. Numerous studies have reported that multiple risk

\footnotetext{
*Correspondence: xingzhoulzu@163.com; yunshancao@126.com ${ }^{5}$ Department of Radiology, Gansu Provincial Hospital, Lanzhou University, Lanzhou 730000, People's Republic of China

'Department of Cardiology, Gansu Provincial Hospital, Lanzhou University, Lanzhou 730000, People's Republic of China

Full list of author information is available at the end of the article
}

factors relate to ST segment elevated MI (STEMI) including male, smoking state, family history of CVD, dyslipidemia, hypertension, and diabetes mellitus (DM) in patients aged < 40 years [3-7]. Familial hypercholesterolemia $(\mathrm{FH})$ as a type of dyslipidemia is one of the most common risk factors in patients with premature atherosclerotic cardiovascular disease (ASCVD) [8, 9]. In addition, previous evidence has proved that the presence of antiphospholipid antibodies (aPL) increases the thrombotic risk and the decreased titers or the disappearance of aPL closely relates to better prognosis [10-13]. Thus, a transient

(c) The Author(s). 2019 Open Access This article is distributed under the terms of the Creative Commons Attribution 4.0 International License (http://creativecommons.org/licenses/by/4.0/), which permits unrestricted use, distribution, and reproduction in any medium, provided you give appropriate credit to the original author(s) and the source, provide a link to the Creative Commons license, and indicate if changes were made. The Creative Commons Public Domain Dedication waiver (http://creativecommons.org/publicdomain/zero/1.0/) applies to the data made available in this article, unless otherwise stated. 
increase of anticardiolipin antibody induced by bacteria or viruses infection may contribute to the risk of thrombosis in patient with possible FH $[14,15]$.

\section{Case presentation}

A 29-year-old male patient had presented with a history of 2-h chest pain and numbness of left upper arm before 5 days. The electrocardiogram (ECG) indicated acute inferior wall myocardial infarction (MI) and he refused any treatment at that time. Five days later he was admitted to our hospital for further examination. Physical examination showed no abnormal including arcus corneae and xanthelasma in eyelid, extensor tendon and achilles tendons. He had no histories of diabetes mellitus, hyperthyroidism, heart disease, hepatic or renal disease and no family history of FH. The ECG showed deep Q wave and inverted T wave in leads II, III and aVF (Fig. 1) and the echocardiogram revealed the diastolic dysfunction of left ventricular with a decreased LV ejection fraction (EF, 48\%). The lower extremities ultrasound revealed atherosclerotic plaque in the posterior wall of right common femoral artery. Blood tests showed CK-MB of $21.4 \mathrm{U} / \mathrm{L}$, lactate dehydrogenase of $452 \mathrm{U} / \mathrm{L}$, hs-CRP of $71.2 \mathrm{ng} / \mathrm{L}$, triglyceride (TG) (Triglyceride Kit method) of $0.88 \mathrm{mmol} / \mathrm{L}$, total cholesterol (TC) of $6.87 \mathrm{mmol} / \mathrm{L}$ (Cholesterol Kitmethod), low density lipoprotein cholesterol (LDL-C) of $5.90 \mathrm{mmol} / \mathrm{L}$ and high density lipoprotein cholesterol (HDL-C) of $1.09 \mathrm{mmol} / \mathrm{L}$ (Direct Method-Surfactant Clearance Method).Further laboratory tests revealed highly elevated anticardiolipin antibody (ELISA method) of more than $120 \mathrm{RU} / \mathrm{ml}(0-12 \mathrm{RU} / \mathrm{ml})$ and no other abnormal auto-antibodies, including $\beta 2$-glicoprotein antibodies IgM, IgA, IgG, lupus anticoagulant (LA). DNA analysis for antiphospholipid antibody syndrome (APS) was not performed. Coronary artery angiography (CAG) demonstrated predominant right coronary artery (RCA) and diffuse lesions in the middle and distal segments of the left anterior descending (LAD) artery with the stenosis up to $40 \sim 50 \%$ (Fig. 2a) and total occlusive RCA from the middle segment (Fig. 2b) with LAD-RCA collateral circulation. With the treatments of anticoagulation (heparin), double antiplatelets (aspirin and ticagrelor) and lipid-modulating (rosuvastatin), he was implanted a stent at the middle segment of the RCA (Fig. 2c). Four days later, he was discharged without any complication. The ECG at discharge showed that the inverted $\mathrm{T}$ waves were deeper than those at admission in leads II, III and aVF (Fig. 3). At 6-month follow-up, the laboratory test showed the level of anticardiolipin antibody (ELISA method) was less than $2.0 \mathrm{RU} / \mathrm{ml}(0-12 \mathrm{RU} / \mathrm{ml})$. Lipid profile revealed TG of $0.98 \mathrm{mmol} / \mathrm{L}$, TC of $6.22 \mathrm{mmol} / \mathrm{L}$, LDL-C of $5.53 \mathrm{mmol} / \mathrm{L}$ and HDL-C of $0.99 \mathrm{mmol} / \mathrm{L} . \mathrm{CAG}$ showed 70\% in-stent restenosis of the RCA. ECG revealed deep $\mathrm{Q}$ waves and inverted $\mathrm{T}$ waves (Fig. 4). The patient looked good without any activity restriction and discomfort. At 8-month follow-up, the level of anticardiolipin antibody is less than $2.0 \mathrm{RU} / \mathrm{ml}$ and the lipid profile showed TG $0.64 \mathrm{mmol} / \mathrm{L}$, TC $4.15 \mathrm{mmol} / \mathrm{L}$, LDL-C 3.47 $\mathrm{mmol} / \mathrm{L}$ and HDL-C $1.01 \mathrm{mmol} / \mathrm{L}$.

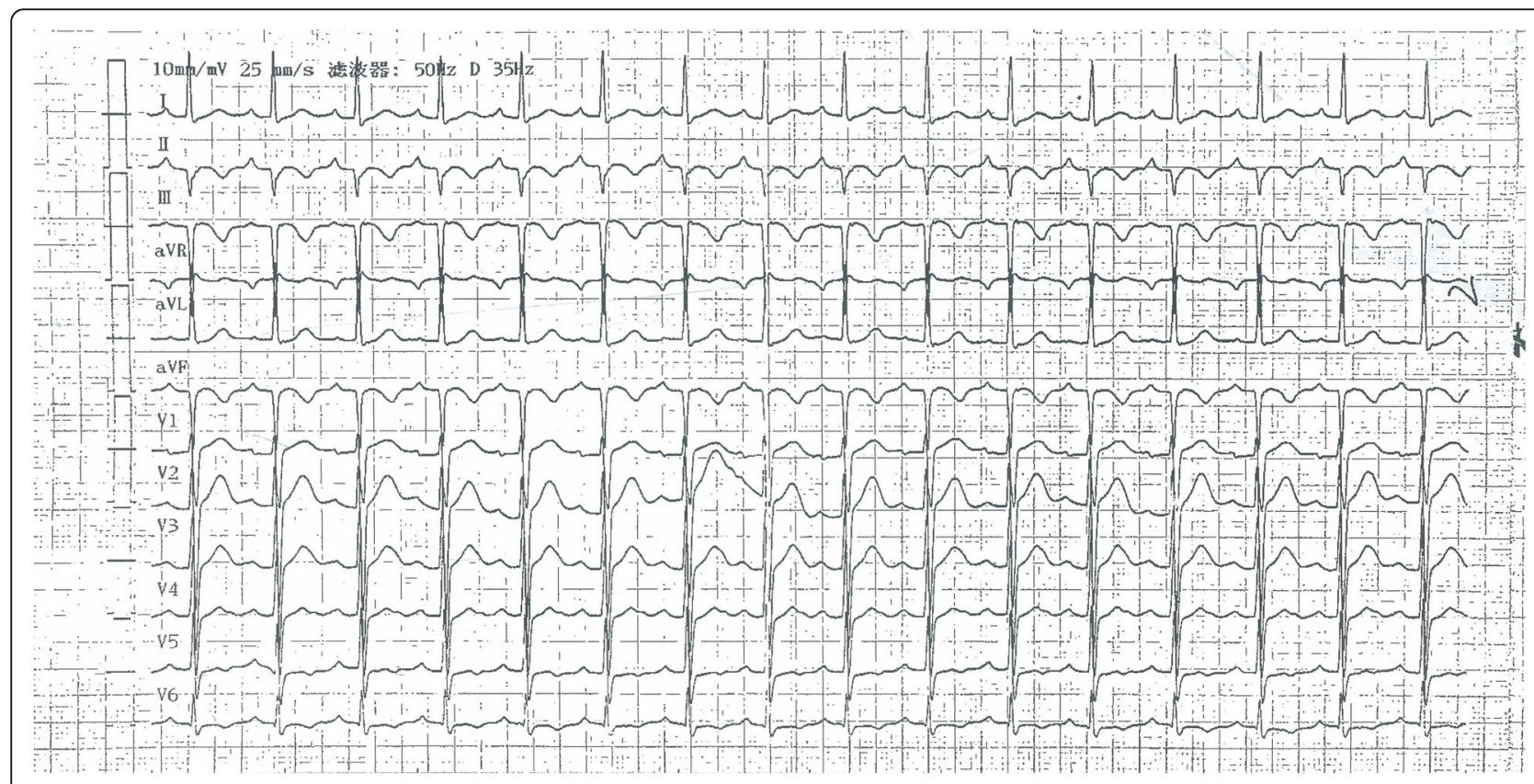

Fig. 1 Electrocardiogram at admission 


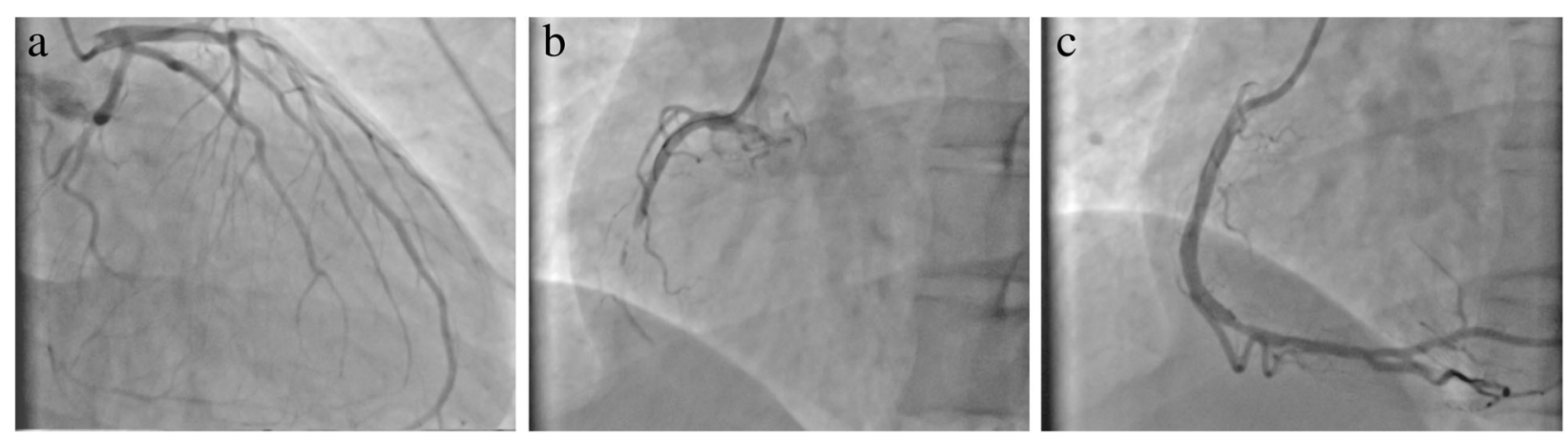

Fig. 2 Coronary artery angiography and percutaneous coronary intervention (PCI). a. Left anterior descending artery (LAD); b. Right coronary artery (RCA); c. Implantation of stent in the middle right coronary artery

\section{Discussion and conclusions}

FH is a risk factor for premature ASCVD [16, 17] and antiphospholipid antibody is a contributor of thrombosis for myocardial infarction [14, 18]. According to the Dutch Lipid Clinic Network (DLCN) Diagnostic criteria (DLCN) [19], the patient was confirmed as possible FH with 5 scores including the premature coronary heart disease ( 2 points) and LDL-C level of $5.90 \mathrm{mmol} / \mathrm{L}$ (3 points). With the International Consensus Statement for Definite APS [20], we could not give a definite diagnosis of APS for this patient. However, the antiphospholipid antibodies can be present in the common population with bacterial or viral infection including $\mathrm{HIV}, \mathrm{HBV}, \mathrm{HCV}$, herpes virus and parvovirus $\mathrm{B} 19[15,21]$. Infection-related antibodies will totally disappear once the infection is gone [22].

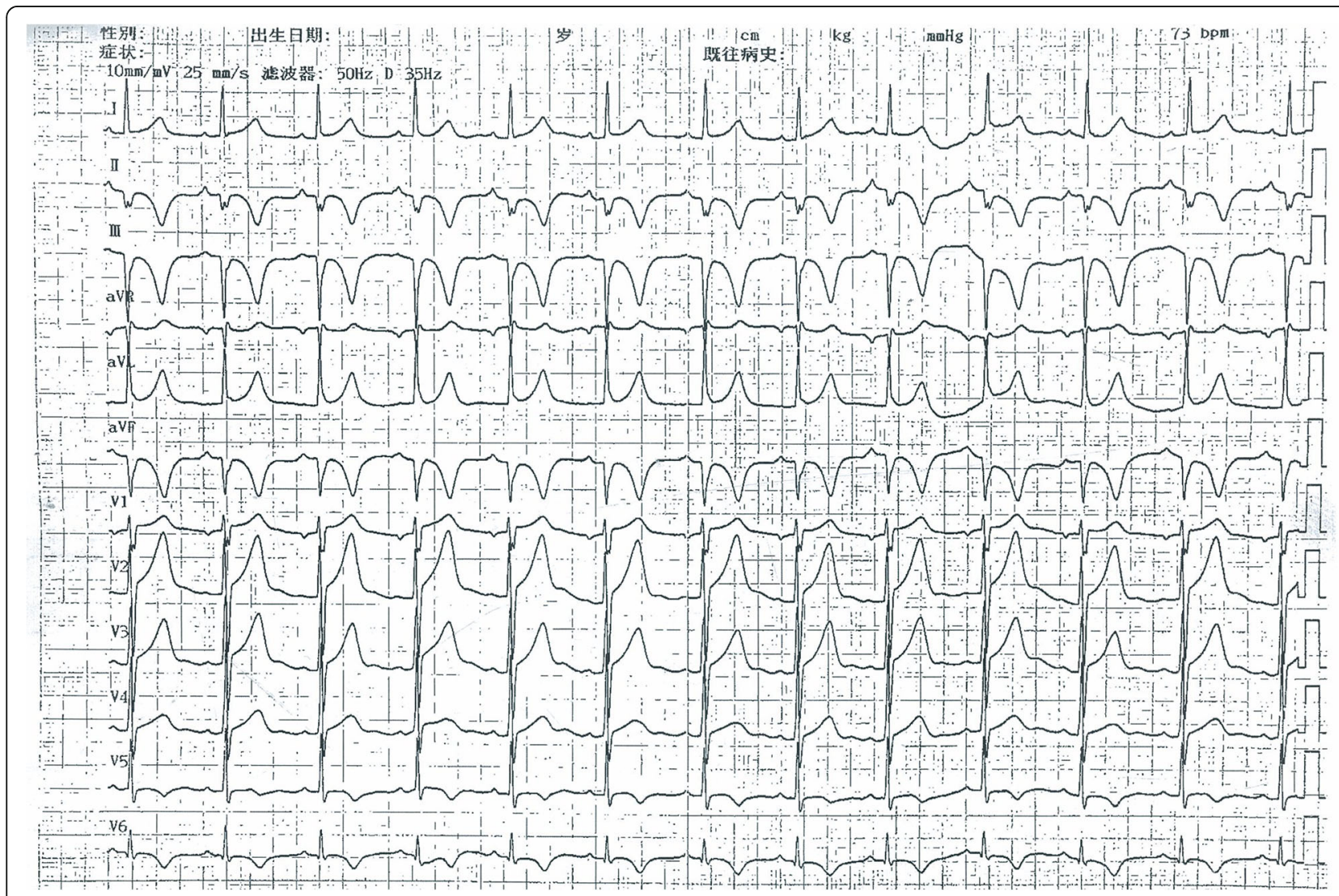

Fig. 3 Electrocardiogram at discharge 


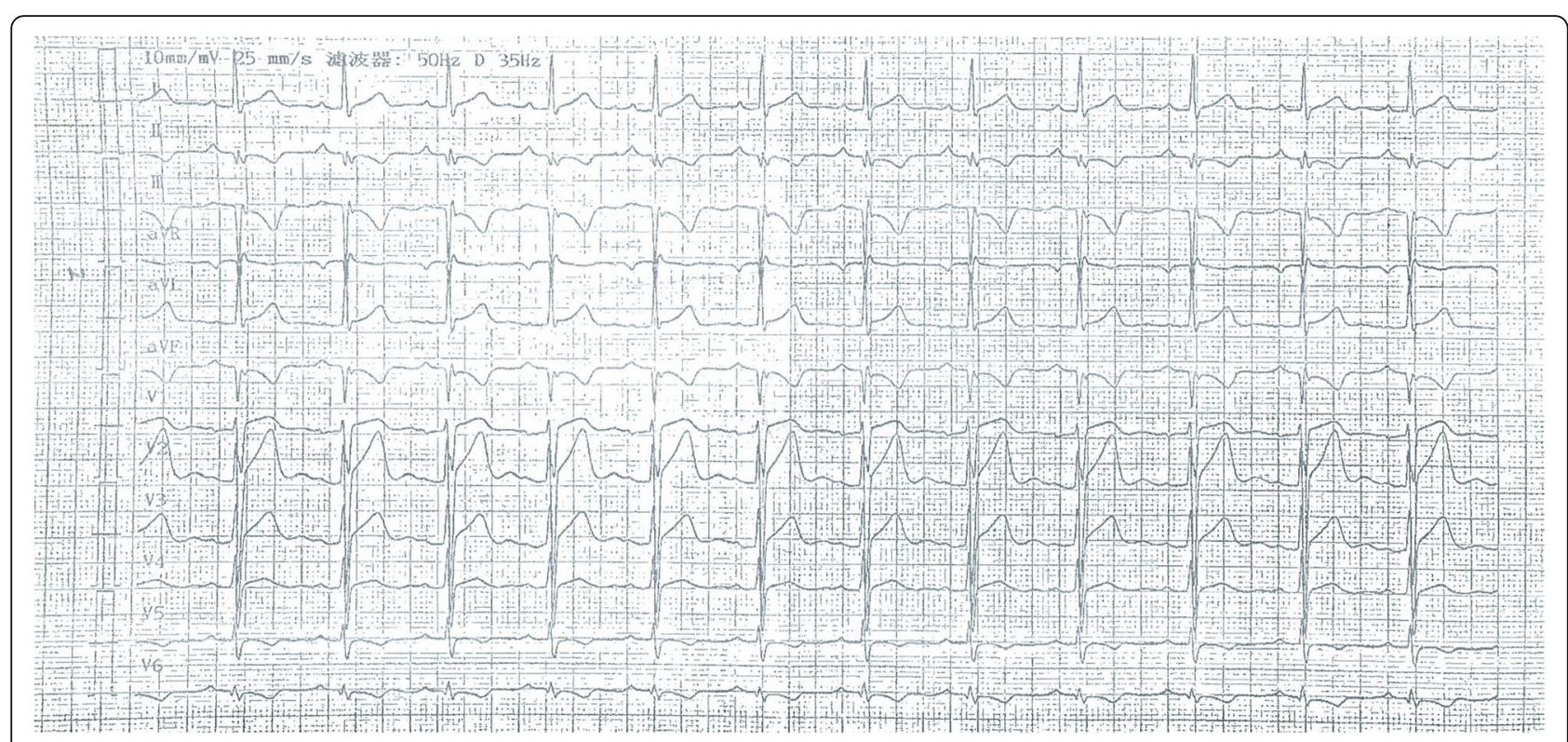

Fig. 4 Electrocardiogram at 6-month follow-up

\begin{abstract}
Although this patient did not have an obvious infectious manifestation before his admission, some occult infections could not be completely excluded. Therefore, transient elevation of anticardiolipin antibody could be a trigger or biomarker for MI in patients with FH [14, 18]; however, the causative effects of transient increased anticardiolipin antibody and MI still need further study.
\end{abstract}

\section{Limitations}

We did not perform the genetic testing about the APS and the test of anticardiolipin antibody at 12-week follow-up.

\section{Abbreviations}

AMI: Acute myocardial infarction; aPL: Antiphospholipid antibody; APS: Antiphospholipid antibody syndrome; ASCVD: Atherosclerotic cardiovascular disease; CAD: Coronary artery disease; CK-MB: Creatine kinase isoenzyme; ECG: Electrocardiograph; FH: Familial hypercholesterolemia; HDL C: High-density lipoprotein cholesterol; hs-CRP: High-sensitivity C-reactive protein; LDL-C: Low-density lipoprotein cholesterol; LDLR: LDL receptor; TC: Total cholesterol; TG: Triglyceride
\end{abstract}

\section{Acknowledgements}

Not Applicable.

\section{Authors' contributions}

$\mathrm{XS}$, AQW were involved in the patient management and manuscript writing. $H Z, H L S, Y C D$ and SLW collected information and collated pictures of the patient. MZ and YH focused on error correction. XZ and YSC performed interventional therapy for the case and revised the manuscript attentively. All the authors read and approved the final manuscript.

\section{Funding}

This work was supported by the National Natural Science Foundation of China (81460072) and CAS "Light of West China" Program where the publication fees are from.

\section{Availability of data and materials}

All the data in this study are included in the manuscript.

Ethics approval and consent to participate

The study is approved by Ethics committee of Gansu Provincial Hospital.

\section{Consent for publication}

We have obtained written informed consent from the patient for the publication.

\section{Competing interests}

The authors have no any conflicts of interests to disclose.

\section{Author details}

'Department of Cardiology, Gansu Provincial Hospital, Lanzhou University, Lanzhou 730000, People's Republic of China. ${ }^{2}$ School of Clinical Medicine, Gansu University of Chinese Medicine, Lanzhou 730000, People's Republic of China. ${ }^{3}$ School of Clinical Medicine, Ningxia Medical University, Lanzhou 730000, People's Republic of China. ${ }^{4}$ Department of Pathology, Gansu Provincial Hospital, Lanzhou University, Lanzhou 730000, People's Republic of China. ${ }^{5}$ Department of Radiology, Gansu Provincial Hospital, Lanzhou University, Lanzhou 730000, People's Republic of China.

Received: 17 October 2018 Accepted: 12 June 2019 Published online: 27 June 2019

\section{References}

1. Trzeciak P, Gierlotka M, Gasior M, Osadnik T, Hawranek M, Lekston A, Zembala M, Polonski L. In-hospital and 12-month outcomes after acute coronary syndrome treatment in patients aged $<40$ years of age (from the polish registry of acute coronary syndromes). Am J Cardiol. 2014; 114(2):175-80.

2. Puricel $S$, Lehner $C$, Oberhansli M, Rutz T, Togni M, Stadelmann M, Moschovitis A, Meier B, Wenaweser P, Windecker S, et al. Acute coronary syndrome in patients younger than 30 years--aetiologies, baseline characteristics and long-term clinical outcome. Swiss Med Wkly. 2013;143: w13816.

3. Yunyun $W$, Tong $L$, Yingwu $L$, Bojiang $L$, Yu W, Xiaomin $H$, Xin L, Wenjin $P$, $\mathrm{Li}$ J. Analysis of risk factors of ST-segment elevation myocardial infarction in young patients. BMC Cardiovasc Disord. 2014;14:179.

4. Hosseini SK, Soleimani A, Karimi AA, Sadeghian S, Darabian S, Abbasi SH, Ahmadi SH, Zoroufian A, Mahmoodian M, Abbasi A. Clinical features, 
management and in-hospital outcome of ST elevation myocardial infarction (STEMI) in young adults under 40 years of age. Monaldi archives for chest disease $=$. Archivio Monaldi per le malattie del torace. 2009;72(2):71-6.

5. Prajapati J, Joshi H, Sahoo S, Virpariya K, Parmar M, Shah K: AGE-Related Differences of Novel Atherosclerotic Risk Factors and Angiographic Profile Among Gujarati Acute Coronary Syndrome Patients. Journal of clinical and diagnostic research : JCDR 2015, 9(6):Oc05-09.

6. Migliaresi P, Celentano A, Palmieri V, Pezzullo S, Martino S, Bonito M, Guillaro B, Brancati C, Di Minno G. Knowledge of cardiovascular risk factors and awareness of non-pharmacological approach for risk prevention in young survivors of acute myocardial infarction. The cardiovascular risk prevention project "help your heart stay young". Nutrition, metabolism, and cardiovascular diseases : NMCD. 2007;17(6):468-72.

7. Callachan EL, Alsheikh-Ali AA, Wallis LA. Analysis of risk factors, presentation, and in-hospital events of very young patients presenting with ST-elevation myocardial infarction. J Saudi Heart Assoc. 2017;29(4):270-5.

8. Vallejo-Vaz AJ, Kondapally Seshasai SR, Cole D, Hovingh GK, Kastelein JJ, Mata P, Raal FJ, Santos RD, Soran H, Watts GF, et al. Familial hypercholesterolaemia: A global call to arms. Atherosclerosis. 2015;243(1):257-9.

9. Pang J, Poulter EB, Bell DA, Bates TR, Jefferson VL, Hillis GS, Schultz CJ, Watts GF. Frequency of familial hypercholesterolemia in patients with early-onset coronary artery disease admitted to a coronary care unit. Journal of clinical lipidology. 2015;9(5):703-8.

10. Salazar-Paramo M, Jara L, Ramos A, Barile L, Machado G. Garcia-De La Torre I: longitudinal study of antinuclear and anticardiolipin antibodies in pregnant women with systemic lupus erythematosus and antiphospholipid syndrome. Rheumatol Int. 2002;22(4):142-7.

11. Turiel M, Sarzi-Puttini P, Peretti R, Rossi E, Atzeni F, Parsons W, Doria A. Thrombotic risk factors in primary antiphospholipid syndrome: a 5-year prospective study. Stroke. 2005;36(7):1490-4.

12. Ruffatti A, Del Ross T, Ciprian M, Bertero MT, Sciascia S, Scarpato S, Montecucco C, Rossi S, Caramaschi P, Biasi D, et al. Risk factors for a first thrombotic event in antiphospholipid antibody carriers: a prospective multicentre follow-up study. Ann Rheum Dis. 2011;70(6):1083-6.

13. Reynaud Q, Lega JC, Mismetti P, Chapelle C, Wahl D, Cathebras P, Laporte S. Risk of venous and arterial thrombosis according to type of antiphospholipid antibodies in adults without systemic lupus erythematosus: a systematic review and meta-analysis. Autoimmun Rev. 2014;13(6):595-608.

14. Schreiber K, Sciascia S, de Groot PG, Devreese K, Jacobsen S, Ruiz-Irastorza G, Salmon JE, Shoenfeld Y, Shovman O, Hunt BJ. Antiphospholipid syndrome. Nature reviews Disease primers. 2018:4:18005.

15. Cruz-Tapias P, Blank M, Anaya JM, Shoenfeld Y. Infections and vaccines in the etiology of antiphospholipid syndrome. Curr Opin Rheumatol. 2012;24(4):389-93.

16. Li S, Zhang Y, Zhu CG, Guo YL, Wu NQ, Gao Y, Qing P, Li XL, Sun J, Liu G, et al. Identification of familial hypercholesterolemia in patients with myocardial infarction: a Chinese cohort study. Journal of clinical lipidology. 2016;10(6):1344-52.

17. Risk of fatal coronary heart disease in familial hypercholesterolaemia Scientific Steering Committee on behalf of the Simon Broome Register Group. BMJ (Clinical research ed) 1991, 303(6807):893-896.

18. Zuckerman E, Toubi E, Shiran A, Sabo E, Shmuel Z, Golan TD, Abinader E, Yeshurun D. Anticardiolipin antibodies and acute myocardial infarction in non-systemic lupus erythmatosus patients: a controlled prospective study. Am J Med. 1996;101(4):381-6.

19. Defesche JC, Lansberg PJ, Umans-Eckenhausen MA, Kastelein JJ. Advanced method for the identification of patients with inherited hypercholesterolemia. Seminars in vascular medicine. 2004;4(1):59-65.

20. Miyakis S, Lockshin MD, Atsumi T, Branch DW, Brey RL, Cervera R, Derksen RH, PG DEG, Koike T, Meroni PL et al: International consensus statement on an update of the classification criteria for definite antiphospholipid syndrome (APS). Journal of thrombosis and haemostasis : JTH 2006, 4(2):295-306.

21. Sene D, Piette JC. Cacoub P: [antiphospholipid antibodies, antiphospholipid syndrome and viral infections]. La Revue de medecine interne. 2009;30(2):135-41.

22. Lieby P, Soley A, Knapp AM, Cerutti M, Freyssinet JM, Pasquali JL, Martin T. Memory B cells producing somatically mutated antiphospholipid antibodies are present in healthy individuals. Blood. 2003;102(7):2459-65

\section{Publisher's Note}

Springer Nature remains neutral with regard to jurisdictional claims in published maps and institutional affiliations.

Ready to submit your research? Choose BMC and benefit from:

- fast, convenient online submission

- thorough peer review by experienced researchers in your field

- rapid publication on acceptance

- support for research data, including large and complex data types

- gold Open Access which fosters wider collaboration and increased citations

- maximum visibility for your research: over $100 \mathrm{M}$ website views per year

At $\mathrm{BMC}$, research is always in progress.

Learn more biomedcentral.com/submissions 